$13^{\text {th }}$ International Conference on

AEROSPACE SCIENCES \& AVIATION TECHNOLOGY,

ASAT - 13, May 26 - 28, 2009, E-Mail: asat@mtc.edu.eg

Military Technical College, Kobry Elkobbah, Cairo, Egypt

Tel : +(202) 24025292 - 24036138, Fax: +(202) 22621908

\title{
Dynamic Behavior of a Hydraulic Braking Valve Incorporating a Hydraulic Servo Actuator
}

\author{
A.H. Draz ${ }^{*}$, M.G. Rabie ${ }^{* *}$, A.I. Abdel-Aziz ${ }^{* * *}$, M.S. Dwidar ${ }^{\dagger}$
}

\begin{abstract}
This paper is dedicated to investigate the static and dynamic behavior of a pilot operated pressure reducing valve (PRV). The valve is the main component in an Anti-skid braking system of a vehicle. This system is fed by the hydraulic power from a constant pressure source. A mathematical model is deduced for the valve. A simulation program is developed using the MATLAB-SIMULINK where the mathematical model is implemented in the program. The developed program is used to study the dynamic valve response due to different input displacement values and effect of varying different design parameters on the overall performance of valve. A conclusion is made to evaluate the valve response and recommendations are suggested to improve valve performance.
\end{abstract}

Keywords: Pilot operated pressure reducing valve - braking system - Fluid power systems

\section{Nomenclature}

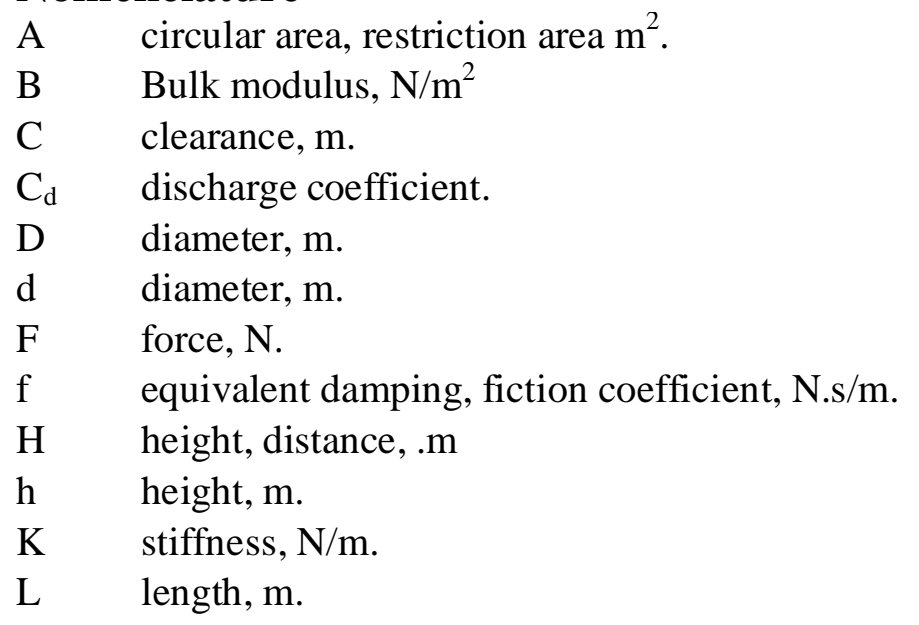

\footnotetext{
* Egyptian Armed Forces

*** Professor of Mechanical Engineering. Modern Academy for Engineering and Technology

*** Dr Eng. Faculty of Engineering, Ain Shams University

${ }^{\dagger}$ Professor of Mechanical Engineering. Faculty of Engineering, Ain Shams University 


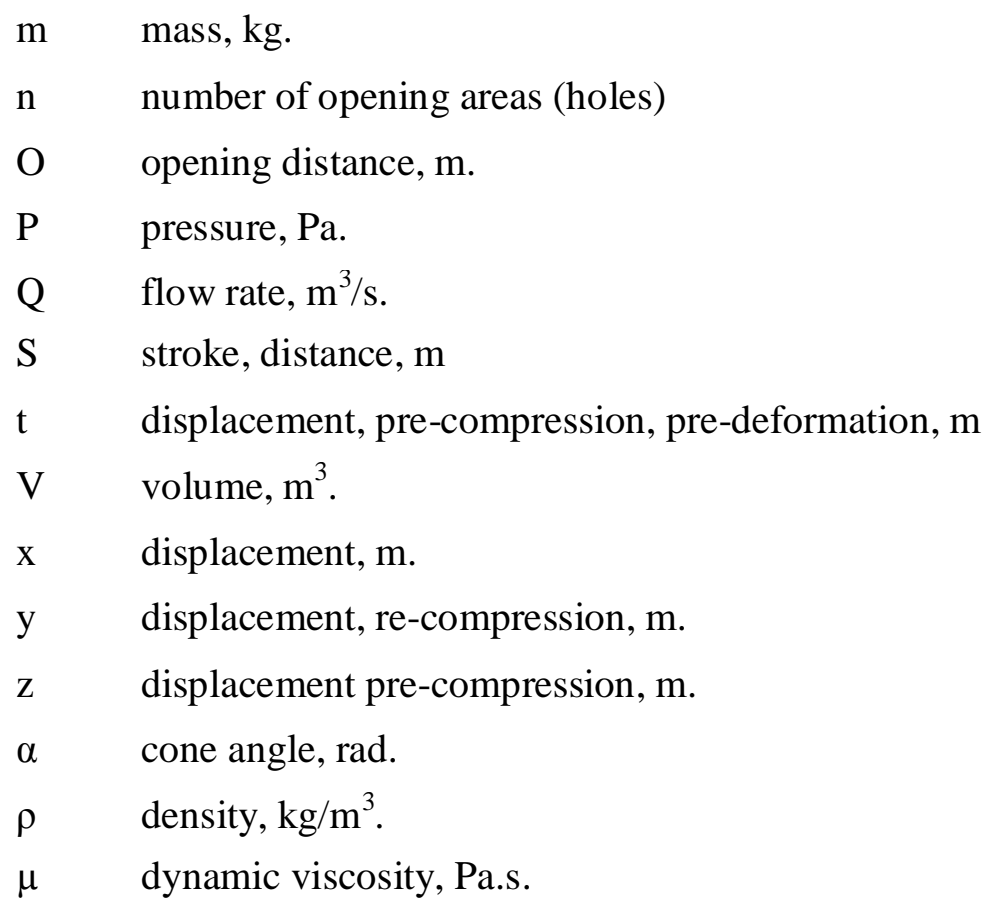

\section{Introduction}

Pressure control valves are divided mainly into three types, pressure relief valves, pressure sequence valves and pressure reducing valves. The pressure reducing valves are used for reduction of input pressure or maintain the output pressure at a set value. There are two types of pressure reducing valves, direct and pilot operated. Scope of study is focused on the pilot operated (servo actuator) pressure reducing valve.

\section{Description}

The valve consists of casing (6) which is central passage used for the arrangement of basic pressure reducer slide valve (11), a relief valve (9), a pilot operated slide control valve (2), a spring block and a damper device (12), (Fig.1).

The basic pressure reducer slide valve (11) has an intake cone. Spring (13) presses the slide valve cone to a sharp edge of sleeve (10). Sleeve (10) separates chambers of the inlet supply pressure $\left(\mathrm{P}_{\mathrm{S}}\right)$ and the reduced pressure for the braking system (chamber B). The relief valve (9) separates chambers of the reduced pressure for the braking system (B) and the return tank pressure (chamber C). Damper (12) installed on the basic pressure reducer slide valve (11) increases the valve stability during operation. Also, a special barrel (8) is installed at the valve outlet. The barrel provides opening an orifice area for fluid passing. 
When pilot pressure is absent, spring (14) returns pilot operated differential piston (3) and the spring block to the initial position. The spring block consists of support (5) and guide (4). The ends of these parts are used as supports for reducing spring (15). The block design provides reducing spring pretension to a required value. Guide (4) can move along support (5) overcoming the force of reducing spring (15).

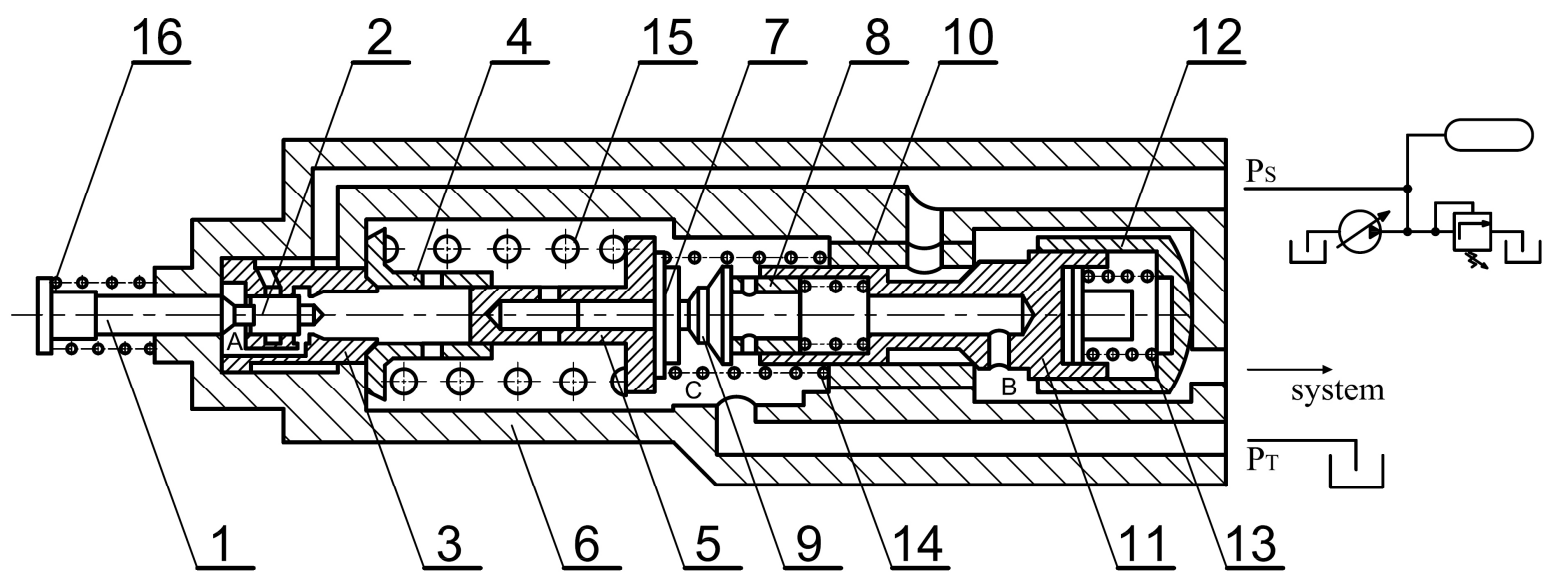

Fig. 1 Schematic diagram of the pilot operated PRV

Beside the basic pressure reducer slide valve, a pilot operated auxiliary control slide valve (2) is used, where piston (3) follows its movement. Control slide valve (2) and rod (1) are rigidly connected and practically unloaded in axial direction. Loading spring (16) is provided on the valve controls to help operator in evaluation of approximate value of reduced pressure by effort on the valve controls.

\section{Operation}

In the valve initial position, shown in Fig.1, the pilot chamber (A) and the brake chamber (B) are connected to the valve return $\left(\mathrm{P}_{\mathrm{T}}\right)$. The inlet supply pressure $\left(\mathrm{P}_{\mathrm{S}}\right)$ is disconnected from these chambers by the intake valve sleeve (10) and a slide valve (11)) and slide control valve (2).

Applying external force $\left(\mathrm{F}_{\mathrm{A}}\right)$ on rod (1), Fig. 2, control slide valve (2) moves to the right with displacement $\left(\mathrm{X}_{\mathrm{A}}\right)$ disconnecting the pilot chamber $(\mathrm{A})$ from the valve return and connects the pilot chamber $(\mathrm{A})$ to the supply pressure $\left(\mathrm{P}_{\mathrm{s}}\right)$.

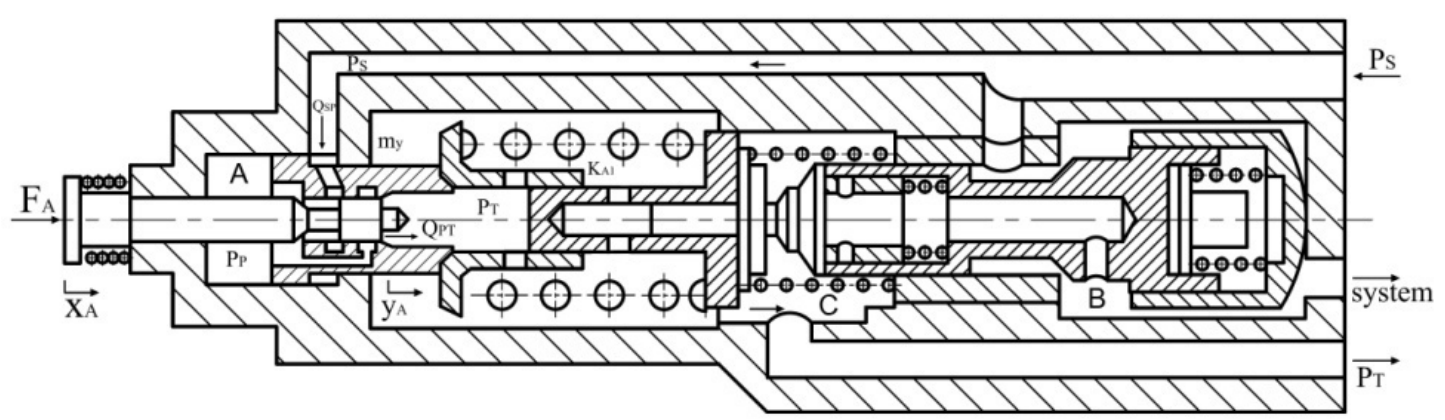

Fig. 2 Schematic diagram of PRV with fluid pressure supplied to braking system 
Increasing pilot pressure $\left(\mathrm{P}_{\mathrm{p}}\right)$ to overcome the friction force, the supply pressure action and the force of return spring (14), piston (3) with the spring block and relief valve (9) moves to the right disconnecting the drain chamber (C) from the brake chamber (B) and moves the basic pressure reducer slide valve (11) opening a passage for the operating fluid into the Brake chamber through opening area formed by sleeve (10) and slide valve (11), refer to Fig. 3.

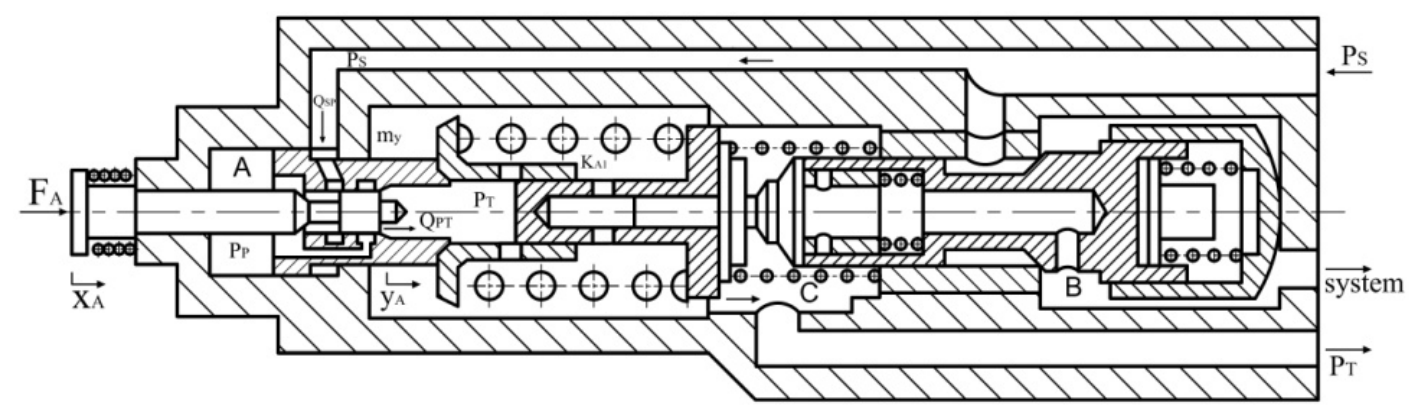

Fig. 3 Schematic diagram of PRV maintain pressure supplied to system

The reduced pressure created in the brake line depends upon the balance of the forces of the damping pressure and return springs (13), (14) acting upon slide valve (11) from one side and the force of reducing spring (15) acting upon the slide valve from the other side. The force of reducing spring (15) and therefore value of reduced pressure are directly proportional to the distance to which piston (3) moves. When the load is removed from rod (1), the valve parts return to the initial position under action of return springs and force of supply pressure acting upon the differential piston (3).

\section{Mathematical Modeling}

The mathematical model of the studied system has been developed for the three valves (2), (9) and (11), the mathematical model considered the nonlinear behavior of the friction between the moving parts and the variable areas in the studied system.

The mathematical model is solved numerically on a digital computer to obtain the dynamic behavior of the system, the equations describing the dynamic behavior of the studied valve are deduced from Fig.(2) considering the following assumptions:-

- The discharge coefficient is assumed constant, $\mathrm{C}_{\mathrm{d}}=0.63$

- The density and bulk's modulus are assumed constant.

- There is no internal or external leakage.

\subsection{Mathematical Modeling of the Pilot Operated Control Slide Valve}

The continuity equation is applied to the pilot control pressure chamber (A) considering rigid walls, constant total oil volume and bulk modulus as follows

$$
\mathrm{Q}_{\mathrm{SP}}-\mathrm{Q}_{\mathrm{PT}}-\left(\mathrm{A}_{\mathrm{AD} 3}-\mathrm{A}_{\mathrm{AD} 1}\right) \frac{\mathrm{dy}_{\mathrm{A}}}{\mathrm{dt}}=\left(\frac{\mathrm{V}_{\mathrm{Po}_{\mathrm{o}}}+\left(\mathrm{A}_{\mathrm{AD} 3}-\mathrm{A}_{\mathrm{AD} 1}\right) \mathrm{y}_{\mathrm{A}}}{\mathrm{B}}\right) \frac{\mathrm{d}}{\mathrm{dt}}\left(\mathrm{P}_{\mathrm{P}}\right)
$$


The flow rates through the pilot operated control slide valve shown in Fig.4. The relations between the flow rates and the system pressures are deduced in the following.

$$
\begin{aligned}
& Q_{\mathrm{SP}}=\mathrm{C}_{\mathrm{d}} \mathrm{A}_{\mathrm{SP}} \sqrt{\frac{2\left(\mathrm{P}_{\mathrm{S}}-\mathrm{P}_{\mathrm{P}}\right)}{\rho}} \\
& \mathrm{Q}_{\mathrm{PT}}=\mathrm{C}_{\mathrm{d}} \mathrm{A}_{\mathrm{PT}} \sqrt{\frac{2\left(\mathrm{P}_{\mathrm{P}}-\mathrm{P}_{\mathrm{T}}\right)}{\rho}}
\end{aligned}
$$

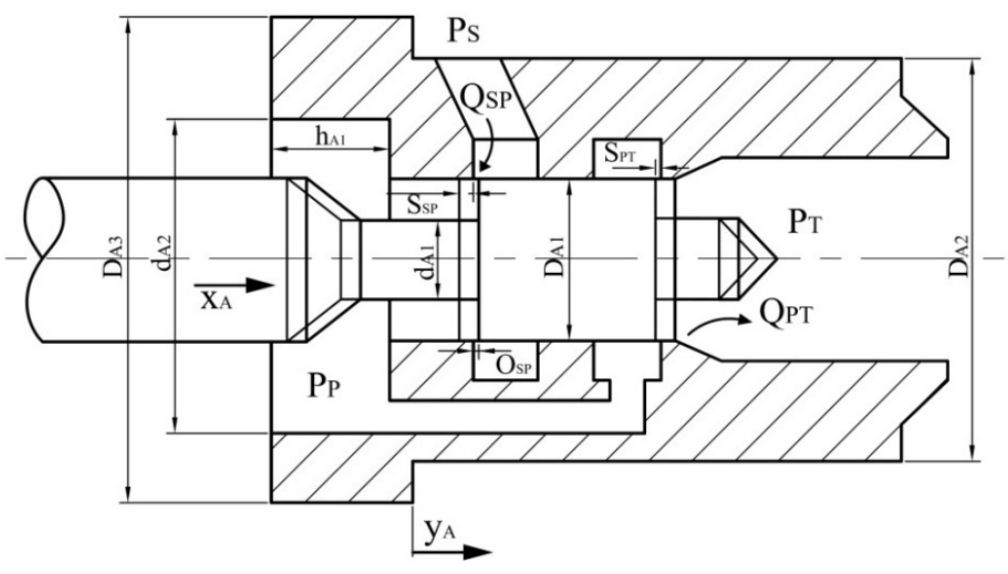

Fig. 4 Functional scheme of pilot operated slide control valve(2)

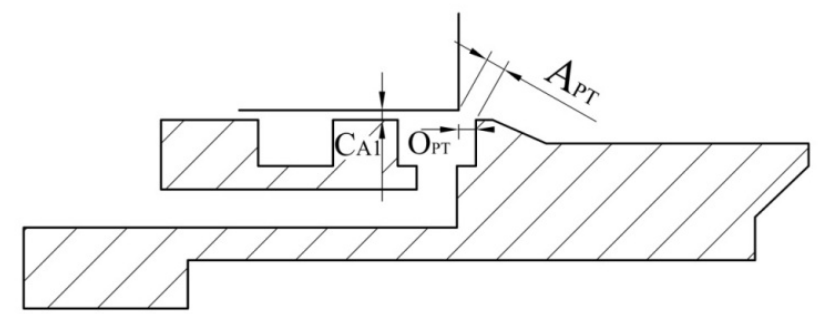

Fig. 5 Variation of the area( $\left.A_{P T}\right)$ of pilot operated slide control valve

As shown in Fig. 5, the area $A_{\mathrm{PT}}$ and consequently the area $\mathrm{A}_{\mathrm{SP}}$ are calculated.

$$
\begin{aligned}
& \mathrm{O}_{\mathrm{PT}}=\left\{\begin{array}{l}
\left(\mathrm{S}_{\mathrm{PT}}-\mathrm{x}_{\mathrm{A}}+\mathrm{y}_{\mathrm{A}}\right) \text { for }\left(\mathrm{x}_{\mathrm{A}}-\mathrm{y}_{\mathrm{A}}\right)<\mathrm{S}_{\mathrm{PT}} \\
\text { Zero for }\left(\mathrm{x}_{\mathrm{A}}-\mathrm{y}_{\mathrm{A}}\right) \geq \mathrm{S}_{\mathrm{PT}}
\end{array}\right. \\
& A_{P T}= \begin{cases}\pi D_{\mathrm{A} 1} \sqrt{\mathrm{O}_{\mathrm{PT}}{ }^{2}+\mathrm{C}_{\mathrm{A} 1}{ }^{2}} \quad \text { for } \mathrm{O}_{\mathrm{PT}}>0 \\
\pi \mathrm{D}_{\mathrm{A} 1} \mathrm{C}_{\mathrm{A} 1} \quad \text { for } \mathrm{O}_{\mathrm{PT}} \leq 0\end{cases} \\
& \mathrm{O}_{\mathrm{SP}}=\left\{\begin{array}{l}
\left(\mathrm{x}_{\mathrm{A}}-\mathrm{y}_{\mathrm{A}}-\mathrm{S}_{\mathrm{SP}}\right) \text { for }\left(\mathrm{x}_{\mathrm{A}}-\mathrm{y}_{\mathrm{A}}\right)>\mathrm{S}_{\mathrm{SP}} \\
\text { Zero for }\left(\mathrm{x}_{\mathrm{A}}-\mathrm{y}_{\mathrm{A}}\right) \leq \mathrm{S}_{\mathrm{SP}}
\end{array}\right.
\end{aligned}
$$


$A_{S P}=\left\{\begin{array}{l}\pi D_{A 1} \sqrt{O_{S P}^{2}+C_{A 1}^{2}} \quad \text { for } O_{S P}>0 \\ \pi D_{A 1} C_{A 1} \quad \text { for } O_{S P} \leq 0\end{array}\right.$

The valve piston moves under the action of the pressure forces, springs forces and jet reaction forces, Fig.6. Neglecting the jet reaction forces, the valve equation of motion is as follows.

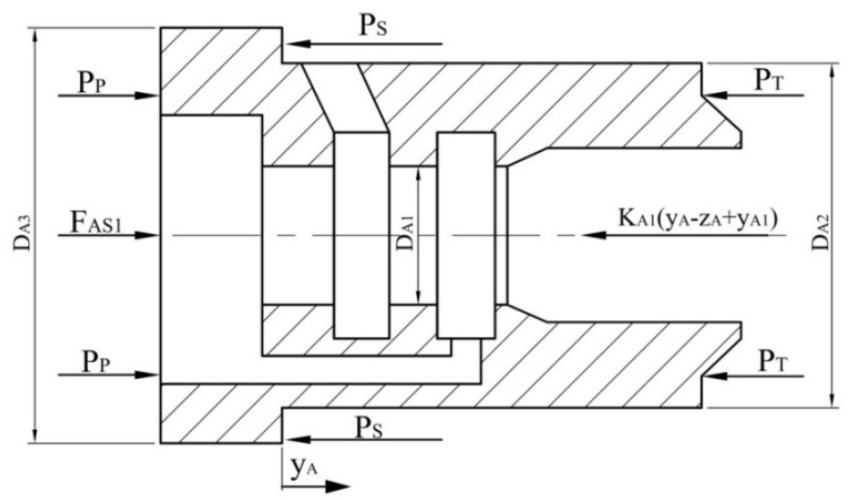

Fig. 6 Piston free body diagram.

$\mathrm{F}_{\mathrm{AS} 1}+\frac{\pi}{4}\left(\mathrm{D}_{\mathrm{A} 3}^{2}-\mathrm{D}_{\mathrm{A} 1}^{2}\right) \mathrm{P}_{\mathrm{P}}-\frac{\pi}{4}\left(\mathrm{D}_{\mathrm{A} 3}^{2}-\mathrm{D}_{\mathrm{A} 2}^{2}\right) \mathrm{P}_{\mathrm{S}}-\frac{\pi}{4}\left(\mathrm{D}_{\mathrm{A} 2}^{2}-\mathrm{D}_{\mathrm{A} 1}^{2}\right) \mathrm{P}_{\mathrm{T}}$

$=\mathrm{m}_{\mathrm{Ay}}\left(\ddot{\mathrm{y}}_{\mathrm{A}}\right)+\mathrm{f}_{\mathrm{Ay}}\left(\dot{\mathrm{y}}_{\mathrm{A}}-\dot{\mathrm{z}}_{\mathrm{A}}\right)+\mathrm{K}_{\mathrm{A} 1}\left(\mathrm{y}_{\mathrm{A}}-\mathrm{z}_{\mathrm{A}}+\mathrm{y}_{\mathrm{A} 1}\right)$

$F_{A S 1}= \begin{cases}-K_{A S 1}\left(y_{A}-y_{A S 1}\right)-f_{A S 1} \dot{y}_{A} & \text { for } y_{A}<y_{A S 1} \\ \text { Zero } \quad \text { for } y_{A} \geq y_{A S 1} & \end{cases}$

It is shown that the seat reaction force $\left(\mathrm{F}_{\mathrm{AS} 1}\right)$ should exist only at the initial position of the piston motion, refer to Fig.1. It disappears as soon as the piston displacement becomes greater than the seat material initial elastic pre-compression. In Eq.4.8 when the rod (1) is at the initial position; input $\mathrm{x}_{\mathrm{A}}=\mathrm{zero}$, then $\mathrm{z}_{\mathrm{A}}=\dot{\mathrm{z}}_{\mathrm{A}}=\ddot{\mathrm{y}}_{\mathrm{A}}=\dot{\mathrm{y}}_{\mathrm{A}}=\mathrm{y}_{\mathrm{A}}=\mathrm{zero}, \mathrm{P}_{\mathrm{p}}=\mathrm{zero}$ and we obtain

$\mathrm{K}_{\mathrm{AS} 1} \mathrm{y}_{\mathrm{AS} 1}-\frac{\pi}{4}\left(\mathrm{D}_{\mathrm{A} 3}^{2}-\mathrm{D}_{\mathrm{A} 2}^{2}\right) \mathrm{P}_{\mathrm{S}}-\frac{\pi}{4}\left(\mathrm{D}_{\mathrm{A} 2}^{2}-\mathrm{D}_{\mathrm{A} 1}^{2}\right) \mathrm{P}_{\mathrm{T}}=\mathrm{K}_{\mathrm{A} 1} \mathrm{y}_{\mathrm{A} 1}$

The seat material initial elastic pre-compression $\left(\mathrm{y}_{\mathrm{AS}}\right)$ as follows

$\mathrm{y}_{\mathrm{AS} 1}=\frac{1}{\mathrm{~K}_{\mathrm{AS} 1}}\left[\frac{\pi}{4}\left(\mathrm{D}_{\mathrm{A} 3}^{2}-\mathrm{D}_{\mathrm{A} 2}^{2}\right) \mathrm{P}_{\mathrm{S}}+\frac{\pi}{4}\left(\mathrm{D}_{\mathrm{A} 2}^{2}-\mathrm{D}_{\mathrm{A} 1}^{2}\right) \mathrm{P}_{\mathrm{T}}+\mathrm{K}_{\mathrm{A} 1} \mathrm{y}_{\mathrm{A} 1}\right]$ 


\subsection{Mathematical Modeling of the Relief Valve and the Pressure Reducer} Applying continuity equation to the damping chamber, Fig. 7, we have

$$
\begin{aligned}
& \frac{\pi}{4} \mathrm{D}_{\mathrm{A} 6}^{2} \frac{\mathrm{dt}_{\mathrm{A}}}{\mathrm{dt}}-\mathrm{Q}_{\mathrm{D}}=\left(\frac{\mathrm{V}_{\mathrm{Do}}-\left(\frac{\pi}{4} \mathrm{D}_{\mathrm{A} 6}^{2}\right) \mathrm{t}_{\mathrm{A}}}{\mathrm{B}}\right) \frac{\mathrm{d}}{\mathrm{dt}}\left(\mathrm{P}_{\mathrm{D}}\right) \\
& \mathrm{V}_{\mathrm{Do}}=\frac{\pi}{4}\left(\mathrm{~d}_{\mathrm{A} 6}^{2} \mathrm{~h}_{\mathrm{A} 3}+\mathrm{D}_{\mathrm{A} 6}^{2} \mathrm{H}_{\mathrm{A} 3}+\mathrm{D}_{\mathrm{A} 5}^{2} \mathrm{~h}_{\mathrm{A} 2}-\mathrm{d}_{\mathrm{A} 5}^{2} \mathrm{H}_{\mathrm{A} 2}\right)
\end{aligned}
$$

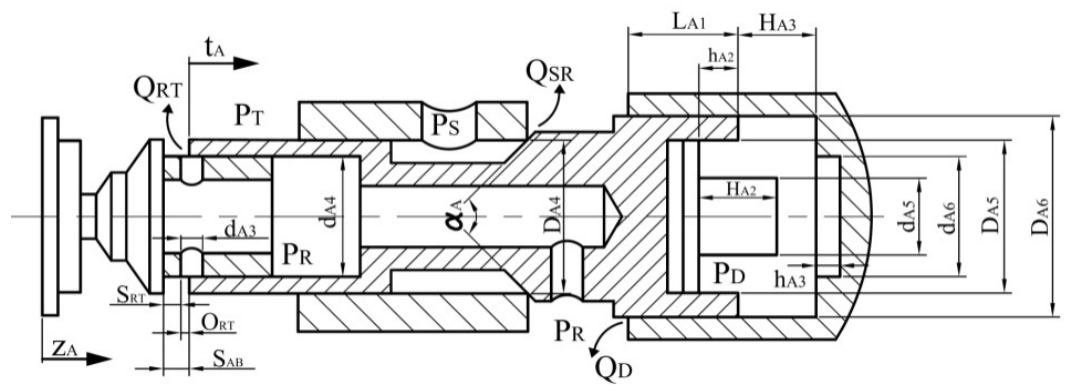

Fig. 7 Schematic of the relief valve and basic pressure reducer slide valve.

Flow rates through the relief valve and the pressure reducer slide valve restriction areas are as follows.

$$
\begin{aligned}
\mathrm{Q}_{\mathrm{SR}} & =\mathrm{C}_{\mathrm{d}} \mathrm{A}_{\mathrm{SR}} \sqrt{\frac{2\left(\mathrm{P}_{\mathrm{S}}-\mathrm{P}_{\mathrm{R}}\right)}{\rho}} \\
\mathrm{Q}_{\mathrm{RT}} & =\mathrm{C}_{\mathrm{d}} \mathrm{A}_{\mathrm{RT}} \sqrt{\frac{2\left(\mathrm{P}_{\mathrm{R}}-\mathrm{P}_{\mathrm{T}}\right)}{\rho}} \\
\mathrm{Q}_{\mathrm{D}} & =\frac{\pi \mathrm{D}_{\mathrm{A} 6} \mathrm{C}_{\mathrm{A} 2}^{3}}{12 \mu\left(\mathrm{L}_{\mathrm{A} 1}+\mathrm{t}_{\mathrm{A}}\right)}\left(\mathrm{P}_{\mathrm{D}}-\mathrm{P}_{\mathrm{R}}\right)
\end{aligned}
$$

The area $\left(\mathrm{A}_{\mathrm{SR}}\right)$ changes nonlinearly with the basic pressure reducer slide valve displacement $\left(\mathrm{t}_{\mathrm{A}}\right)$, it is found that

$$
\mathrm{A}_{\mathrm{SR}}=\left\{\begin{array}{lr}
\text { Zero } & 0 \leq \mathrm{t}_{\mathrm{A}} \leq \mathrm{t}_{\mathrm{AS} 2} \\
\left(\mathrm{t}_{\mathrm{A}}-\mathrm{t}_{\mathrm{AS} 2}\right) \sin \left(\frac{\propto}{2}\right)\left[\mathrm{D}_{\mathrm{A} 4}-\left(\mathrm{t}_{\mathrm{A}}-\mathrm{t}_{\mathrm{AS} 2}\right) \sin \left(\frac{\propto}{2}\right) \cos \left(\frac{\propto}{2}\right)\right] & \mathrm{t}_{\mathrm{A}}>\mathrm{t}_{\mathrm{AS} 2}
\end{array}\right.
$$

The area $A_{R T}$ is the throttling area that occurs by displacement of the barrel (8) inward the pressure reducer slide valve (11), Fig. (8), throttling the flow through the holes in the barrel (8).

The throttling area $A_{R T}$ is expressed by 


$$
\begin{aligned}
& \mathrm{A}_{\mathrm{RT}}=\left\{\begin{array}{lr}
\mathrm{n}_{\mathrm{Ah}} \frac{\pi}{4} \mathrm{~d}_{\mathrm{A} 3}^{2} & \mathrm{O}_{\mathrm{RT}} \geq \mathrm{d}_{\mathrm{A} 3} \\
\mathrm{n}_{\mathrm{Ah}}\left(\frac{\pi}{4} \mathrm{~d}_{\mathrm{A} 3}^{2}-\mathrm{A}\right) & \mathrm{d}_{\mathrm{A} 3}>\mathrm{O}_{\mathrm{RT}}>\frac{\mathrm{d}_{\mathrm{A} 3}}{2} \\
\mathrm{n}_{\mathrm{Ah}} \mathrm{A} & \frac{\mathrm{d}_{\mathrm{A} 3}}{2} \geq \mathrm{O}_{\mathrm{RT}} \geq \text { zero }
\end{array}\right. \\
& \mathrm{A}=\frac{1}{2}\left[2 \frac{\mathrm{d}_{\mathrm{A} 3}^{2}}{2} \sin ^{-1}\left(\frac{\sqrt{2 \mathrm{O}_{\mathrm{RT}} \frac{\mathrm{d}_{\mathrm{A} 3}}{2}-\mathrm{O}_{\mathrm{RT}}^{2}}}{\frac{\mathrm{d}_{\mathrm{A} 3}}{2}}\right)-\left(2 \sqrt{2 \mathrm{O}_{\mathrm{RT}} \frac{\mathrm{d}_{\mathrm{A} 3}}{2}-\mathrm{O}_{\mathrm{RT}}{ }^{2}}\right)\left(\frac{\mathrm{d}_{\mathrm{A} 3}}{2}-\mathrm{O}_{\mathrm{RT}}\right)\right] \\
& \text { (1) }
\end{aligned}
$$

Fig. 8 Throttling areas in the relief valve.

The pressure reducer slide valve reaction acts on the relief valve only when the basic pressure reducer slide valve and the relief valve are in contact, Fig. 9. The reduced (Brake) pressure force acts on the relief valve only when the last closes and the reduced (Brake) pressure are built. The mass of the relief valve $\left(\mathrm{m}_{\mathrm{Az}}\right)$ is subjected to the spring (15) force from one side and to the spring (14) force from the opposite side, refer to Fig.1. Neglecting the jet reaction forces then,

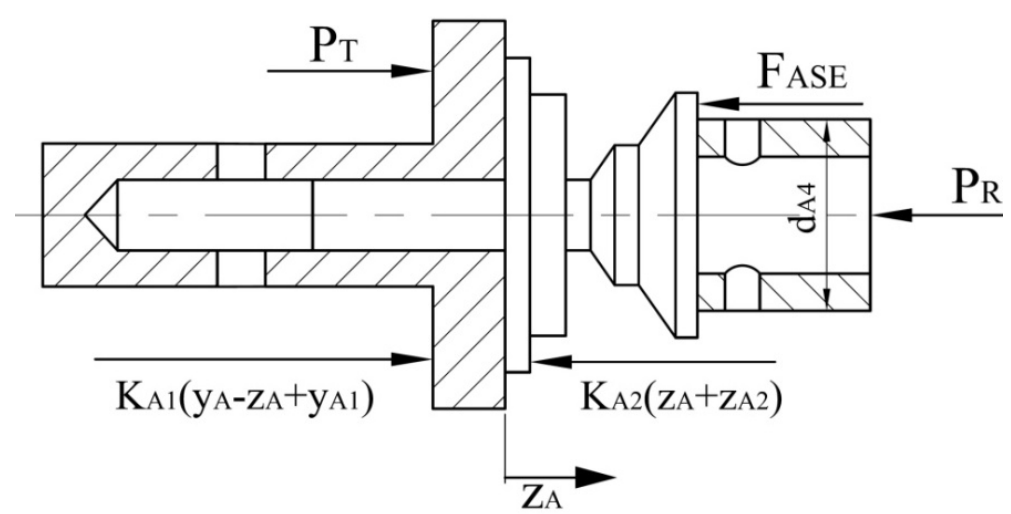

Fig. 9 The relief valve free body diagram. 
$\frac{\pi}{4} \mathrm{~d}_{\mathrm{A} 4}^{2}\left(\mathrm{P}_{\mathrm{T}}-\mathrm{P}_{\mathrm{R}}\right)-\mathrm{F}_{\mathrm{ASE}}=\mathrm{m}_{\mathrm{Az}} \ddot{\mathrm{z}}_{\mathrm{A}}+\mathrm{f}_{\mathrm{Az}}\left(\dot{\mathrm{z}}_{\mathrm{A}}-\dot{\mathrm{y}}_{\mathrm{A}}\right)+\mathrm{K}_{\mathrm{A} 2}\left(\mathrm{z}_{\mathrm{A}}+\mathrm{z}_{\mathrm{A} 2}\right)+\mathrm{K}_{\mathrm{A} 1}\left(\mathrm{z}_{\mathrm{A}}-\mathrm{y}_{\mathrm{A}}-\mathrm{y}_{\mathrm{A} 1}\right)$

$$
\mathrm{F}_{\mathrm{ASE}}=\left\{\begin{array}{lr}
\mathrm{K}_{\mathrm{ASE}}\left(\mathrm{z}_{\mathrm{A}}-\mathrm{S}_{\mathrm{AB}}-\mathrm{t}_{\mathrm{A}}\right)+\mathrm{f}_{\mathrm{ASE}}\left(\dot{\mathrm{Z}}_{\mathrm{A}}-\dot{\mathrm{t}}_{\mathrm{A}}\right) & \left(\mathrm{Z}_{\mathrm{A}}-\mathrm{t}_{\mathrm{A}}\right)>\mathrm{S}_{\mathrm{AB}} \\
\text { Zero } & \left(\mathrm{Z}_{\mathrm{A}}-\mathrm{t}_{\mathrm{A}}\right)<\mathrm{S}_{\mathrm{AB}}
\end{array}\right.
$$

It is assumed that the change in the Brake chamber volume and the other connected chambers volume are so small compared to the whole volume change. applying continuity equation to Brake chamber, Fig.(7)

$$
\mathrm{Q}_{\mathrm{SR}}+\mathrm{Q}_{\mathrm{D}}-\mathrm{Q}_{\mathrm{RT}}=\left(\frac{\mathrm{V}_{\mathrm{BPo}}}{\mathrm{B}}\right) \frac{\mathrm{d}}{\mathrm{dt}}\left(\mathrm{P}_{\mathrm{R}}\right)
$$

The valve becomes in equilibrium under the action of the pressure forces, springs forces and jet reaction forces, refer to Fig.10.

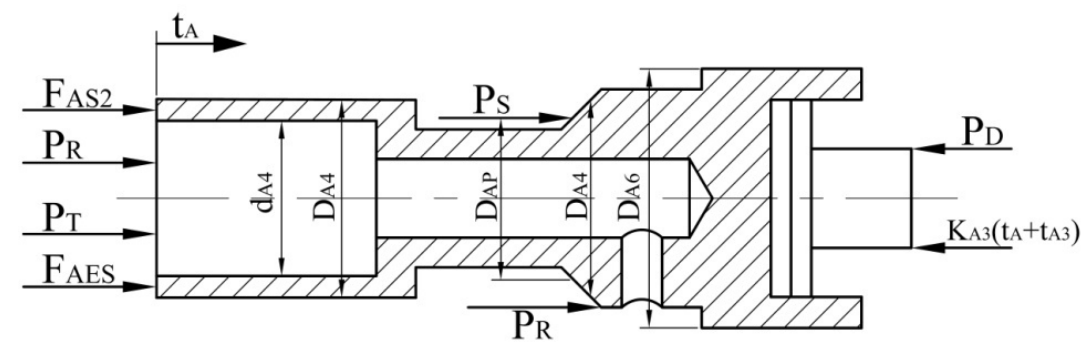

Fig. 10 The basic pressure reducer slide valve free body diagram.

There is a reaction force $\left(\mathrm{F}_{\mathrm{AES}}\right)$ between the relief valve and pressure reducer slide valve only when both valves are in contact. The sleeve seat reaction $\left(\mathrm{F}_{\mathrm{AS} 2}\right)$ exists only when the basic pressure reducer slide valve contacts the sleeve. It disappears as soon as the basic pressure reducer slide valve displaces a distance greater than the sleeve seat material initial elastic precompression. Neglecting the jet reaction forces then

$$
\begin{gathered}
\frac{\pi}{4}\left(\mathrm{~d}_{\mathrm{A} 4}^{2}+\mathrm{D}_{\mathrm{A} 6}^{2}-\mathrm{D}_{\mathrm{AP}}^{2}\right) \mathrm{P}_{\mathrm{R}}+\frac{\pi}{4}\left(\mathrm{D}_{\mathrm{A} 4}^{2}-\mathrm{d}_{\mathrm{A} 4}^{2}\right) \mathrm{P}_{\mathrm{T}}-\frac{\pi}{4}\left(\mathrm{D}_{\mathrm{A} 4}^{2}-\mathrm{D}_{\mathrm{AP}}^{2}\right) \mathrm{P}_{\mathrm{S}}-\frac{\pi}{4} \mathrm{D}_{\mathrm{A} 6}^{2} \mathrm{P}_{\mathrm{D}} \\
+\mathrm{F}_{\mathrm{AES}}+\mathrm{F}_{\mathrm{AS} 2}=\mathrm{m}_{\mathrm{At}} \ddot{\mathrm{t}}_{\mathrm{A}}+\mathrm{f}_{\mathrm{At}} \dot{\mathrm{t}}_{\mathrm{A}}+\mathrm{K}_{\mathrm{A} 3}\left(\mathrm{t}_{\mathrm{A}}+\mathrm{t}_{\mathrm{A} 3}\right) \\
\mathrm{F}_{\mathrm{AES}}=\left\{\begin{array}{lr}
\mathrm{K}_{\mathrm{AES}}\left(\mathrm{z}_{\mathrm{A}}-\mathrm{S}_{\mathrm{AB}}-\mathrm{t}_{\mathrm{A}}\right)+\mathrm{f}_{\mathrm{AES}}\left(\dot{\mathrm{z}}_{\mathrm{A}}-\dot{\mathrm{t}}_{\mathrm{A}}\right) & \left(\mathrm{z}_{\mathrm{A}}-\mathrm{t}_{\mathrm{A}}\right)>\mathrm{S}_{\mathrm{AB}} \\
\text { Zero } & \left(\mathrm{z}_{\mathrm{A}}-\mathrm{t}_{\mathrm{A}}\right) \leq \mathrm{S}_{\mathrm{AB}}
\end{array}\right. \\
\mathrm{F}_{\mathrm{AS} 2}=\left\{\begin{array}{lr}
-\mathrm{K}_{\mathrm{AS} 2}\left(\mathrm{t}_{\mathrm{A}}-\mathrm{t}_{\mathrm{AS} 2}\right)-\mathrm{f}_{\mathrm{AS} 2} \dot{\mathrm{t}}_{\mathrm{A}} & \mathrm{t}_{\mathrm{A}}<\mathrm{t}_{\mathrm{AS} 2} \\
\text { Zero } & \mathrm{t}_{\mathrm{A}} \geq \mathrm{t}_{\mathrm{AS} 2}
\end{array}\right.
\end{gathered}
$$




\section{Simulation and Analysis of the Braking Valve}

The deduced mathematical model was used to develop a simulation program using the MATLAB-SIMULINK software. The valve behavior was studied through different response figures for different inputs. Therefore, the valve behavior can be discussed.

\subsection{Effect of Different Inlet System Pressures $\left(\mathbf{P}_{\mathrm{s}}\right)$ on Control Slide Valve Piston Displacement $\left(\mathbf{Y}_{\mathrm{a}}\right)$}

Fig. 11 shows the response of piston displacement $\left(\mathrm{y}_{\mathrm{A}}\right)$ for step input displacement $\mathrm{x}_{\mathrm{A}}=30 \mathrm{~mm}$ at $\mathrm{t}=0.01 \mathrm{~s}$. with different system inlet pressures.

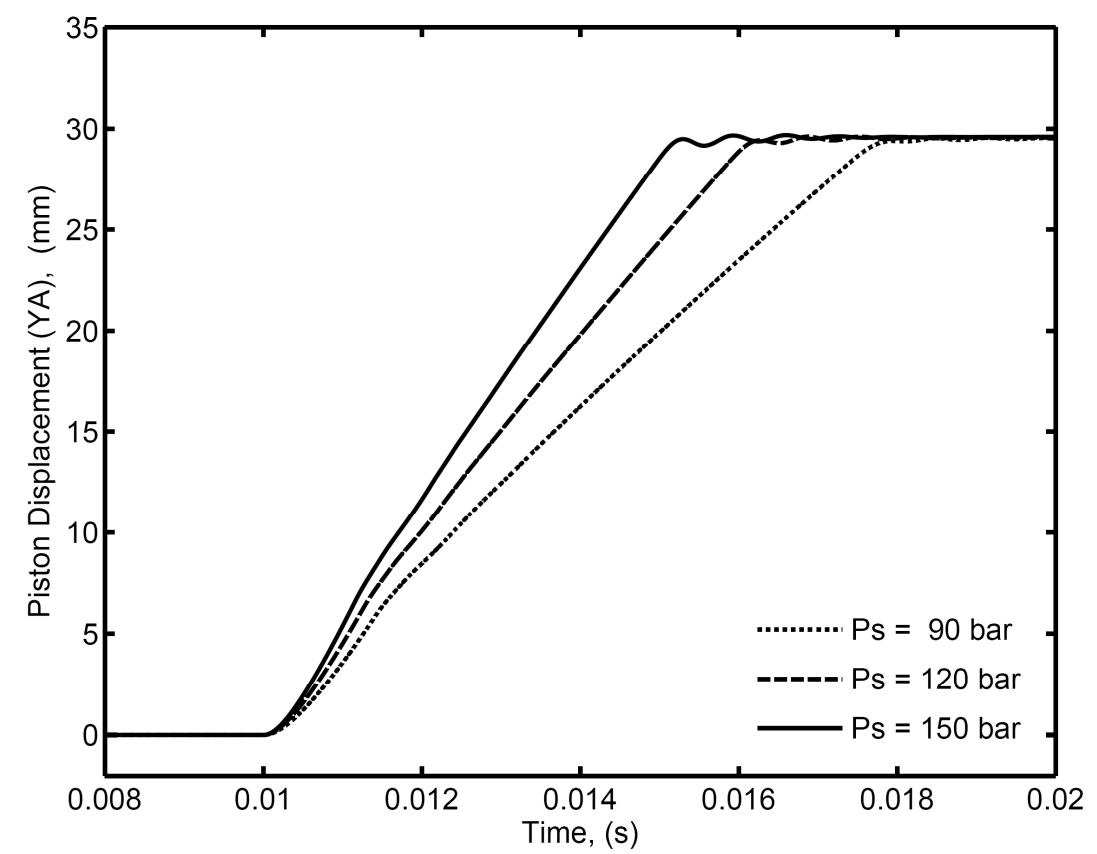

Fig. 11 Piston displacement $\left(Y_{A}\right)$ response for step input displacement $X_{A}=30 \mathrm{~mm}$ at different inlet system pressures introduced to slide valve at $t=0.01 \mathrm{~s}$.

\subsection{Effect of Reduced Pressure Increase over the Cracking Pressure of Relief Valve} To check the dynamic response of the relief valve a step input of the reduced pressure $\Delta \mathrm{P}_{\mathrm{R}}=30$ bar was introduced at $\mathrm{t}=0.03 \mathrm{~s}$ and stopped at $\mathrm{t}=0.05 \mathrm{~s}$ during a step input displacement $\mathrm{x}_{\mathrm{A}}=35$ $\mathrm{mm}$ at $0.01 \mathrm{~s}$.

The obtained responses, Fig. 12, shows stabilization of reduced pressure at a value of $100 \mathrm{bar}$ at $\mathrm{t}$ $=0.018 \mathrm{~s}$. at $\mathrm{t}=0.03 \mathrm{~s}$ (time of introducing external pressure $\Delta \mathrm{P}_{\mathrm{R}}=30 \mathrm{bar}$ ) reduced pressure begins to increase till it reaches a maximum (cracking) value of 106 bar at $t=0.05 \mathrm{~s}$, where flow rate through valve is directed to return tank maintaining the reduced pressure at a value less than cracking pressure. Finally, pressure stabilizes again at 100 bar at $t=0.058 \mathrm{~s}$ and relief valve closes. 
This indicates that the reduced pressure for the braking system is stabilizing in $8 \mathrm{mSec}$ after the disturbance to the reduced pressure finished at $\mathrm{t}=0.05$, this is prove that the dynamic response of the studied valve is achieved with this design.

\subsection{Effect of Change in Input Displacement $\left(x_{A}\right)$ on the Output Reduced Pressure} In order to check the main function required by the brake valve, a step input displacement $\mathrm{x}_{\mathrm{A}}=35 \mathrm{~mm}$ was introduced at $\mathrm{t}=0.01 \mathrm{~s}$ followed by a decrease of input displacement to a value $\mathrm{x}_{\mathrm{A}}=32 \mathrm{~mm}$ at $\mathrm{t}=0.03 \mathrm{~s}$.

The obtained responses are shown in Fig.13. At $t=0.03 \mathrm{~s}$, change of input displacement $\left(X_{A}\right)$ results in decrease of spring (15) force, followed by decrease in relief valve displacement $\left(Z_{A}\right)$ decreasing reduced pressure to stabilize at 44 bar.

\subsection{Effect of Reducing Spring Stiffness}

Fig. 13 shows the response of the reduced pressure $\left(\mathrm{P}_{\mathrm{r}}\right)$. The input to rod (1) is a step input displacement with a value $3.5 \mathrm{~cm}$ delayed $0.005 \mathrm{~s}$, at different stiffness values of reducing spring (15), Fig.1. The system pressure is 150 bar and the tank pressure is zero.

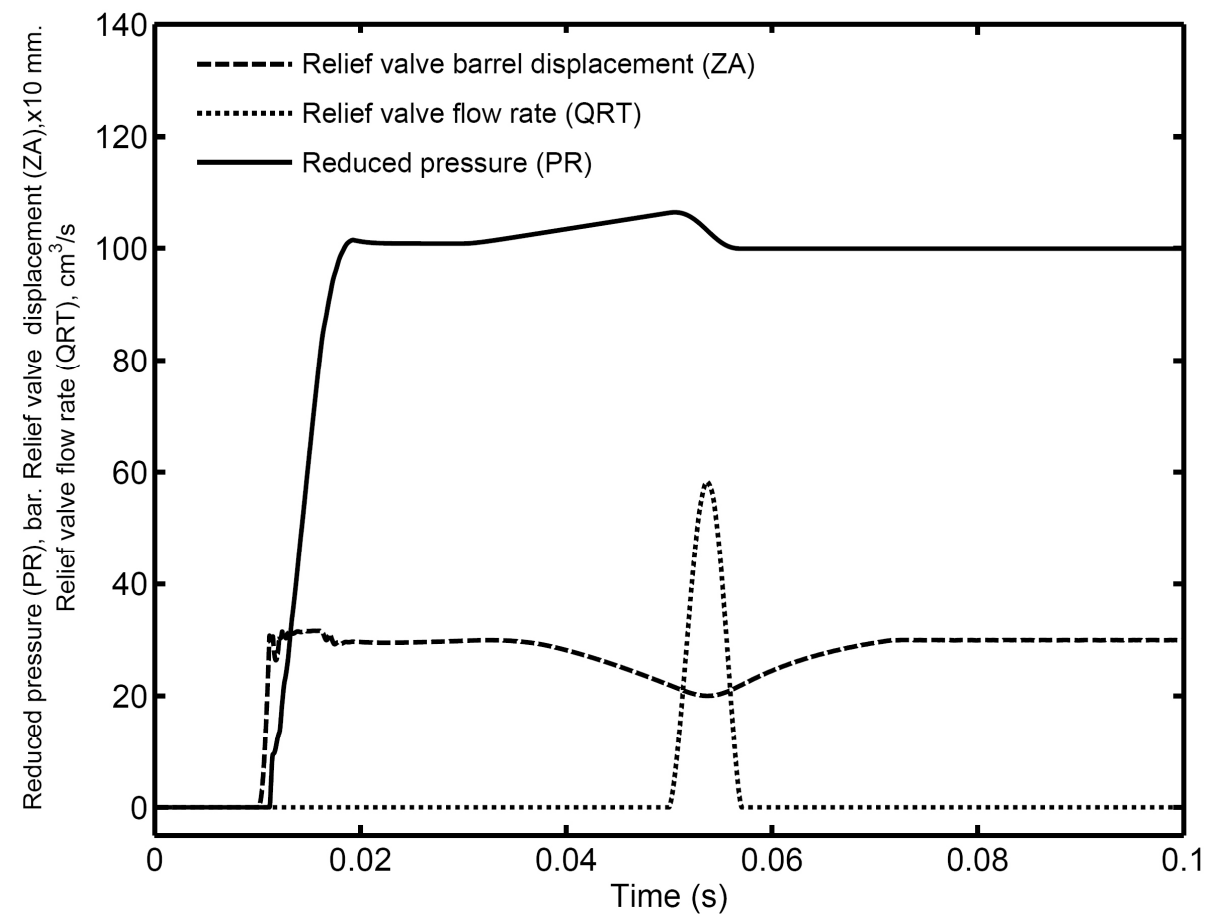

Fig. 12 Reduced pressure $\left(P_{R}\right)$, Relief valve displacement $\left(Z_{A}\right) \&$ relief valve flow rate $\left(Q_{R T}\right)$ responses for step input displacement $x_{A}=35 \mathrm{~mm}$ at $t=0.01 \mathrm{~s}$, external increase in reduced pressure $\Delta P_{R}=30$ bar introduced at $t=0.03 \mathrm{~s}$. 


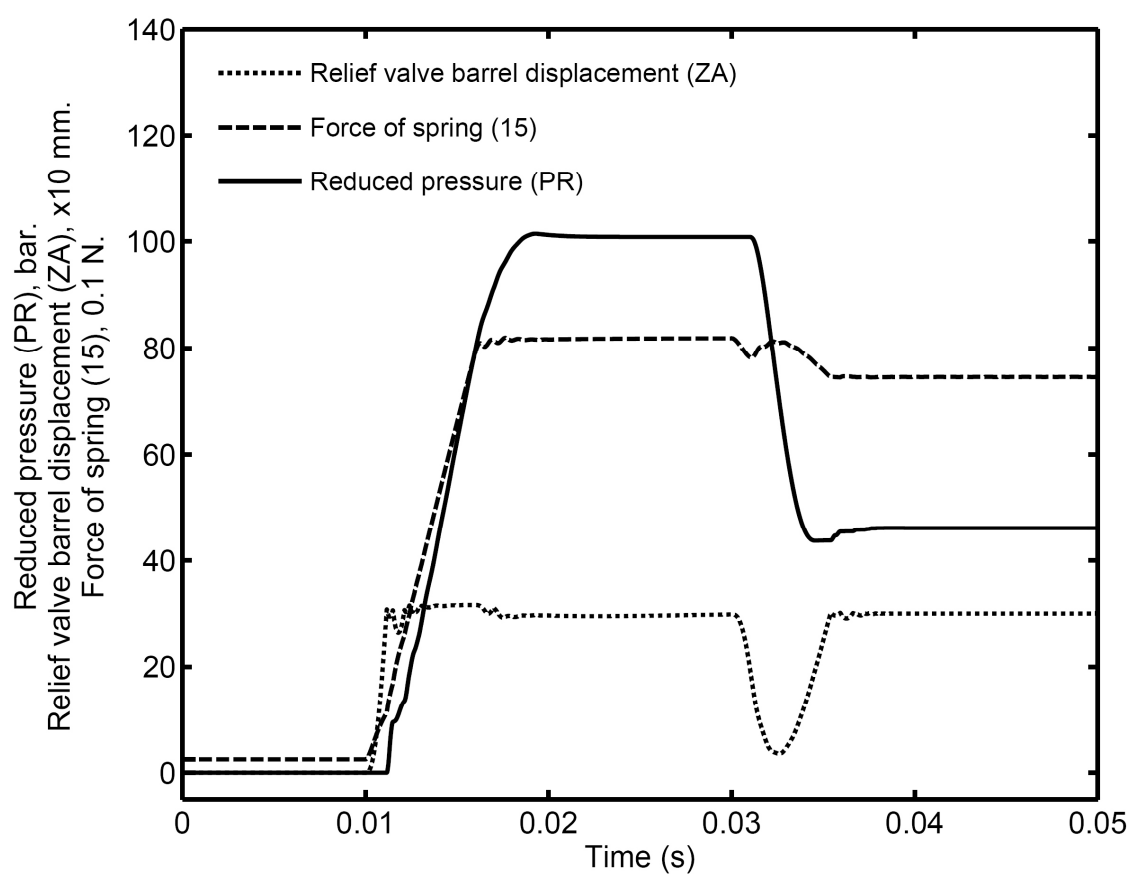

Fig. 13 Reduced pressure $\left(P_{R}\right)$, force of spring (15) and relief valve displacement $\left(Z_{A}\right)$ responses for change in step input displacement $\left(\Delta X_{A}\right)=3 \mathrm{~mm}$ at $t=0.03 \mathrm{~s}$.

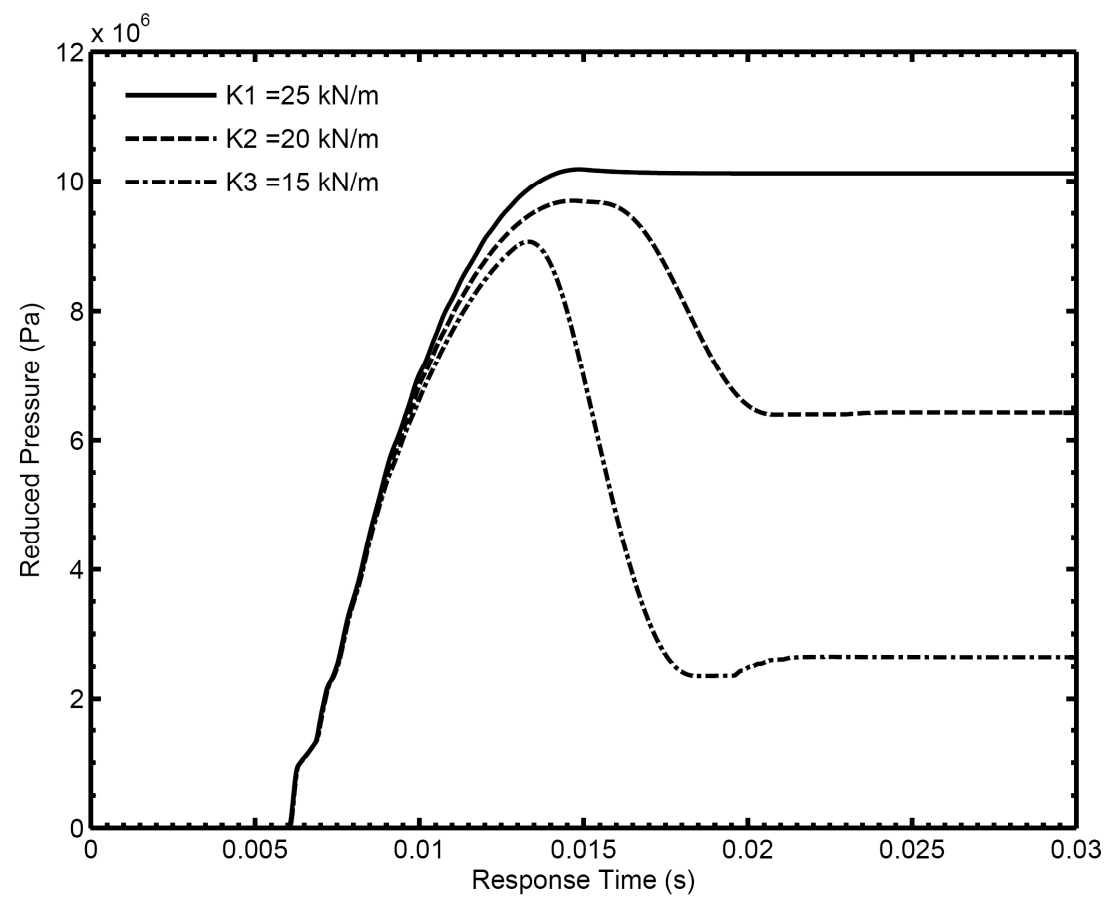

Fig. 14 The reduced pressure response to step input $3.5 \mathrm{~cm}$ at different stiffness values of reducing spring. 
The less the value of stiffness, the less the final steady state value of the reduced pressure, the greater the maximum overshoot, the greater the settling time, the less the delay time, the less the rise time.

The decrease of the spring (15) stiffness deteriorate the dynamic response of the reduced pressure , it causes a higher over shot of the pressure to the braking system which can cause the locking of the wheel of used vehicle and the purpose of the anti-braking system does not achieved

\subsection{Effect of Radial Clearance of Damping Chamber}

Fig. 15 shows the response of the reduced pressure. The input displacement to rod (1) is a step input with a step time of $(0.005 \mathrm{~s}$.), zero initial value and a final value $(3.5 \mathrm{~cm}$.), at different radial clearance values of damping device (12), Fig. 14. The system pressure is 150 bar and the tank pressure is zero.

There is an optimum radial clearance. The less the value of radial clearance, nearly the same the final steady state value of the reduced pressure but the greater the maximum overshoot, the greater the settling time, the greater the delay time, the greater the rise time. And the greater than that optimum value, the less the final steady state value of the reduced pressure, the greater the maximum overshoot, the greater the settling time, but the less the delay time, the less the rise time.

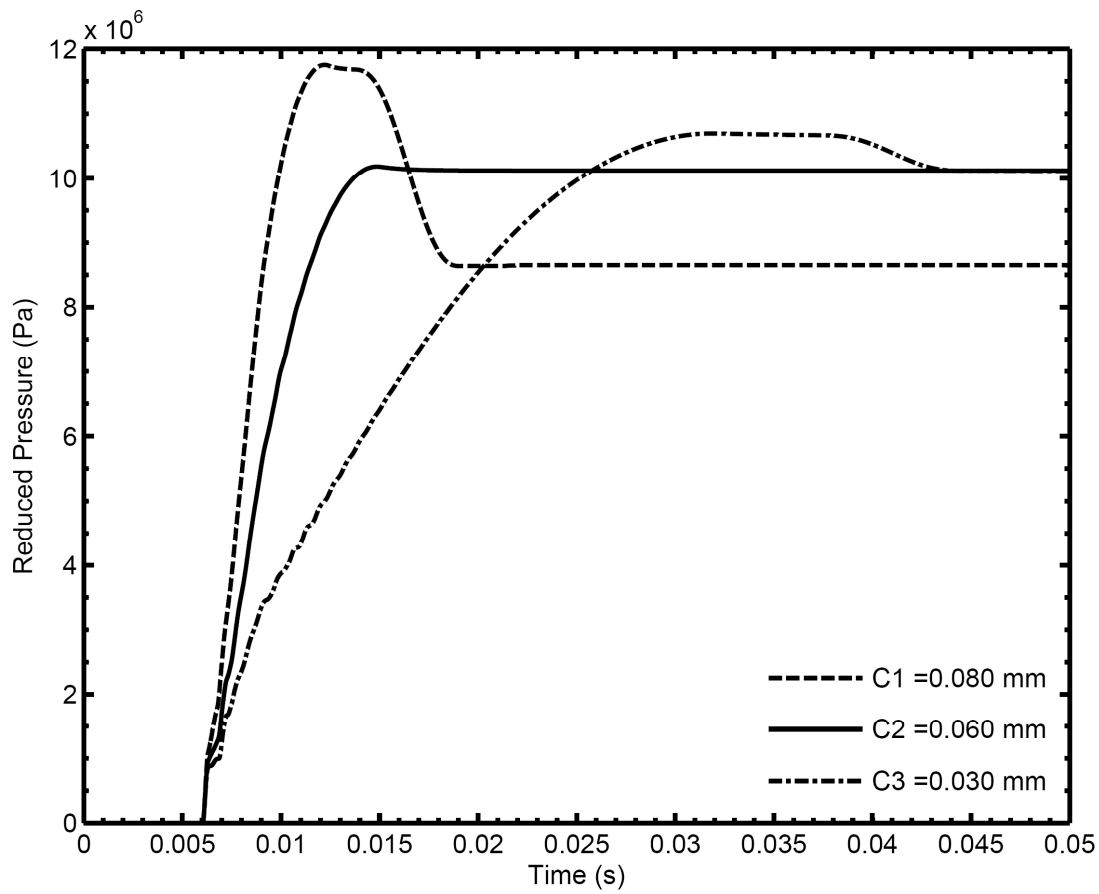

Fig. 15 The reduced pressure response to step input $3.5 \mathrm{~cm}$ at different radial clearance values of damping device 


\subsection{Effect of Barrel Outer Diameter}

Fig. 16 shows the response of the reduced pressure. The input displacement to rod (1) is a step input with a step time of $0.005 \mathrm{~s}$, zero initial value and a final value of $3.5 \mathrm{~cm}$, at different outer diameter values of barrel (8). The system pressure is 150 bar and the tank pressure is zero.

The greater the value of barrel outer diameter, the less the final steady state value of the reduced pressure, the greater the maximum overshoot, the greater the settling time, the less the delay time, the less the rise time.

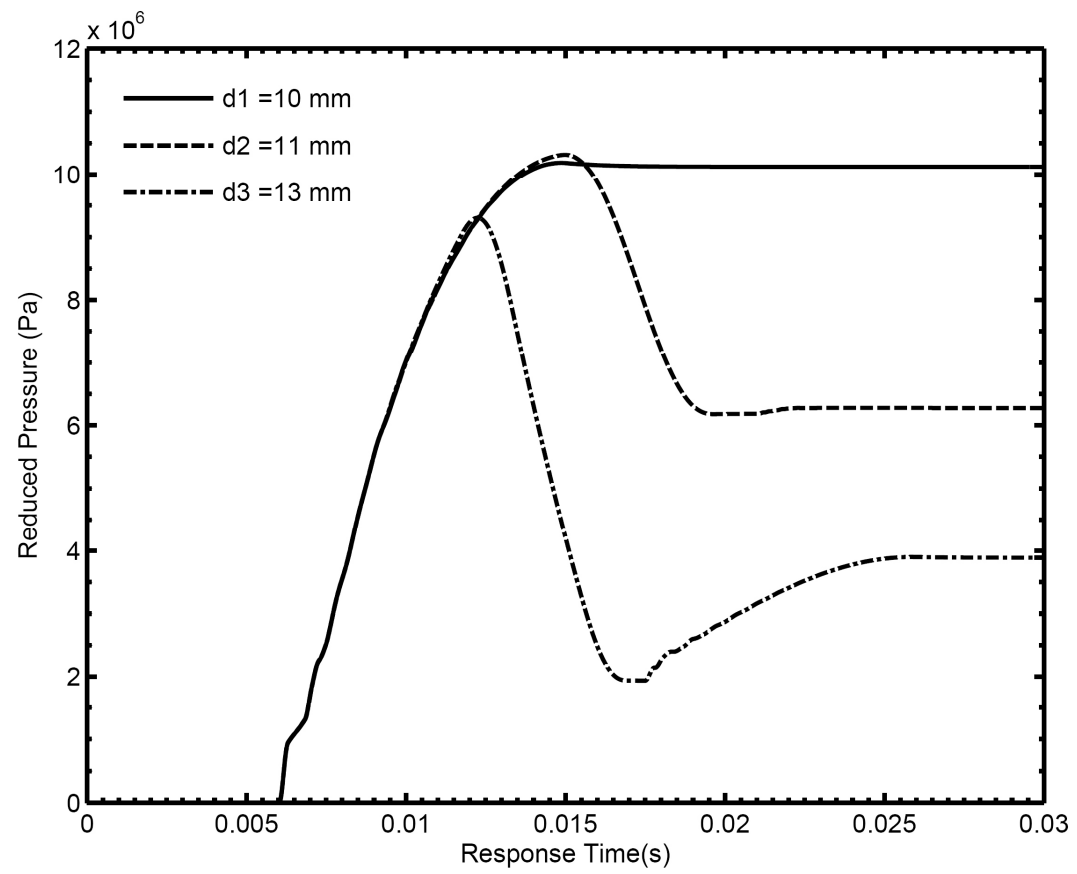

Fig. 16 The reduced pressure response to step input $3.5 \mathrm{~cm}$ at different outer diameter values of barrel.

\section{Conclusions and Recommendations}

The dynamic behavior of the braking vale in an anti skid braking system of a vehicle was investigated. The study included the deduction of the mathematical model describing the dynamic performance of the studied valve and the development of a simulation program using the MATLAB package.

The valve is subjected to different step input displacement and change of different constructional parameters to investigate the dynamic behavior of the valve in order to improve its dynamic response. It is found that the braking valve is affected by the changing of the inlet pressure $\left(\mathrm{P}_{\mathrm{s}}\right)$. With the increase of inlet pressure, the rise time of the piston displacement in pressure reducing valve is decreased, but its value slightly fluctuated, and this is deteriorate the function of braking system due to the fluctuation of its required pressure. 
It is found that the spring stiffness is chosen correctly for the required working pressure (100 bar) and changing the stiffness deteriorate the function of pressure reducing valve affecting the predetermined value of reduced pressure

It is found that the radial clearance of damping chamber plays the main role in the dynamic performance of the braking valve. It is clear that there is optimum value for this clearance to rabidly set the braking system pressure to predetermined value, but this indicates the sensitivity of this design in case of increasing this clearance due to the wear.

\section{Acknowledgment}

The authors are indebted to Dr Ziad Ibrahim for his comments on this text.

\section{References}

[1] M. Galal RABIE, Fluid Power Engineering, McGraw-Hill, NY, 2009

[2] P. Smith, Valve Selection Handbook, fifth edition, Burlington, USA, 2004

[3] Matlab Reference Guide - The Math Works Inc, 1997

[4] Mannesmann Rexroth GmbH, Basic Principles and Components of Fluid Technology, volume 1, 1999. 